\title{
PENGARUH EKSTRAK JERUK NIPIS TERHADAP PENGHAMBATAN PERTUMBUHAN VIBRIO SPP PADA IKAN KERAPU MACAN
}

\author{
Rafiudin $^{1}$, Farida Bahalwan ${ }^{2}$ \\ ${ }^{1}$ Program Studi Pendidikan Biologi Universitas Muslim Maros, Sulawesi Selatan \\ ${ }^{2}$ Program Studi Pendidikan Biologi. Universitas Darusalam Ambon \\ ${ }^{1}$ E-mail: rafimudri@gmail.com
}

\begin{abstract}
Abstrak: Hasil penelitian pengujian ekstrak jeruk nipis (Citrus aurantifolia) terhadap penghambatan pertumbuhan bakteri Vibrio sp. pada ikan kerapu macan (Epinephelus fuscogatattus) menghasilkan nilai rerata untuk kontrol $(0,62 \mathrm{~cm})$, konsentrasi $10 \%(0,79$ $\mathrm{cm}), 20 \%(0,79 \mathrm{~cm})$ serta konsentrasi $30 \%(0,8 \mathrm{~cm})$. Sehingga pengujian hipotesis dengan menggunakan rumus ANAVA ternyata $F_{\text {hitung }}>F_{\text {tabel }}$ pada taraf signifikan 5\% sebesar 4,07 yang berarti 20,535 > 4,07. Ini membuktikan bahwa ekstrak jeruk nipis (Citrus aurantifolia) dapat menghambat pertumbuhan bakteri Vibrio sp. pada ikan kerapu macan (Epinephelus fuscogatattus) dan besar pengaruh ekstrak jeruk nipis (Citrus aurantifolia) terhadap pertumbuhan bakteri Vibrio sp. pada ikan kerapu macan (Epinephelus fuscogatattus) adalah $0,06 \%$..
\end{abstract}

\section{Kata Kunci: Ekstrak Jeruk Nipis, Ikan Kerapu Macan, Vibrio sp}

Ikan kerapu (Family serranidae) tersebar luas di wilayah perairan tropis dan subtropis serta merupakan makanan laut yang paling favorit di dunia dan merupakan salah satu jenis spesies ikan yang paling populer diantara spesies ikan yang hidup di karang yang menjadi komoditas perikanan di wilayah Asia Pasifik. Komoditas ikan laut jenis kerapu (Epinephelus $s p$ ) merupakan jenis yang paling banyak diminati untuk dibudidayakan, karena pertumbuhannya cepat, dalam 12 bulan bisa mencapai ukuran 5-6 kg. Ada beberapa jenis ikan kerapu yang dibudidaya dengan menggunakan sistem budidaya dan pembesaran ditambak.

Ikan kerapu macan (Epinephelus fuscogatattus) merupaka jenis ikan laut komersial yang mulai banyak dibudidayakan orang, baik untuk pembenihan maupun pembesarannya karena menjanjikan prospek yang baik. Jenis ikan kerapu lain yang dapat dibudidayakan adalah kerapu sunu (Plectomorphus leopardus), kerapu bebek (Chrommileptes altivelis), kerapu naga (Epinephelus lanceolatus), dan kerapu lumpur (Epinephelus coioides). Ikan kerapu macan (Epinephelus fuscogatattus) atau juga disebut groouper dipasarkan dalam keadaan hidup dan memiliki nilai ekonomis yang sangat tinggi. Jenis ikan kerapu ini merupakan ikan asli indonesia yang hidup tersebar diberbagai perairan berkarang diindonesia (Sumatera, Jawa, Sulawesi, Pulau Buru, dan Ambon).

Infeksi bakteri merupakan penyebab kematian masal pada benih ikan kerapu. Penyakit yang disebabkan oleh bakteri Vibrio sp ini merupakan masalah yang sangat 
serius dan umum menyerang ikan-ikan budidaya laut. Penularannya dapat melalui air atau kontak langsung antar ikan dan menyebar sangat cepat pada ikan-ikan yang dipelihara dengan kepadatan tinggi. Salah satu kendala dalam budidaya kerapu adalah serangan penyakit vibriosis yang disebabkan oleh bakteri Vibrio. Penyakit ini merupakan penyakit bakterial utama, terutama pada benih yang dapat menimbulkan kematian sampai $100 \%$ dalam waktu 2 minggu. Beberapa spesies bakteri vibrio yang sering diisolasi dari ikan Kerapu yang sakit adalah vibrio alginolyticus, vibrio anguillarum, vibrio vulnivicus. Taslihan mengemukakan bahwa vibrio alginolyticus merupakan bakteri patogen utama pada budidaya ikan Kerapu.

Penelitian Wijayati dan Hamid, membuktikan bahwa bakteri yang menginfeksi ikan kerapu stadia larva, fingerling, maupun induk adalah bakteri Vibrio dari jenis vibrio anguilarum, vibrio parahaemoliticus, vibrio alginolyticus, dan vibrio marinus. Kasonchandra, mengemukakan bahwa vibrio parahaemolyticus dan vibrio alginolyticus berperan sebagai penyebab kematian pada ikan laut hingga mencapai $80-90 \%$. Seng, mengemukakan bahwa pada ikan kerapu bakteri $V$. alginolyticus dan $V$. parahaemolyticus merupakan penyebab kematian yang potensial. Yanuhar, menyebutkan bahwa mortalitas ikan kerapu stadia larva $(1-3 \mathrm{~cm})$ dan fingerling $(7-15)$ terjadi hinga 90 $100 \%$.

Pada dasarnya jeruk nipis (Citrus aurantifolia) sudah banyak dikenal oleh masyarakat indonesia sebagai tanaman berkhasiat, yang merupakan salah satu upaya untuk penanggulangan masalah kesehatan yang dihadapi. Jauh sebelum pelayanan kesehatan formal dengan obat-obatan modern yang menyentuh masyarakat. Pengetahuan tentang obat ini merupakan warisan budaya bangsa berdasarkan pengalaman yang secara turun menurun telah diwariskan oleh generasi terdahulu kepada generasi saat ini. Obat tradisoanal adalah ramuan dari tumbuh-tumbuhan yang yang berkhasiat. Jeruk nipis (Citrus aurantifolia) merupakan salah satu tanaman yang selama ini dimanfaatkan oleh masyarakat untuk keperluan sehari-hari, mulai dari minuman, masakan, obat-obatan, bahkan digunakan sebagai zat aktif yang bisa membunuh bakteri.

\section{METODE PENELITIAN}

Rancangan yang digunakan dalam penelitian ini adalah Rancangan Acak Lengkap (RAL), dengan 4 kali perlakuan dan 3 kali ulangan. Adapun perlakuan tersebut adalah sebagai berikut :

$\mathrm{P}_{0}$ : Biakan murni bakteri Vibrio sp ditambah aquades $10 \mathrm{ml}$ (kontrol)

$\mathrm{P}_{1}$ : Biakan murni bakteri Vibrio $s p$ ditambah ekstrak jeruk nipis $10 \%$.

$\mathrm{P}_{2}$ : Biakan murni bakteri Vibrio $s p$ ditambah ekstrak jeruk nipis $20 \%$.

$\mathrm{P}_{3}$ : Biakan murni bakteri Vibrio sp ditambah ekstrak jeruk nipis $30 \%$. 
Tabel 1. Rancangan Penelitian

\begin{tabular}{|c|c|c|c|c|}
\hline \multirow{2}{*}{ Perlakuan } & \multicolumn{3}{|c|}{ Ulangan } & \multirow{2}{*}{$\Sigma$} \\
\cline { 2 - 4 } & I & II & III & \\
\hline $\mathrm{P}_{0}$ & $\mathrm{P}_{0 \text { I }}$ & $\mathrm{P}_{0 \text { II }}$ & $\mathrm{P}_{0 \text { III }}$ & \\
\hline $\mathrm{P}_{1}$ & $\mathrm{P}_{1 \text { I }}$ & $\mathrm{P}_{1 \text { II }}$ & $\mathrm{P}_{1 \text { III }}$ & \\
\hline $\mathrm{P}_{2}$ & $\mathrm{P}_{2 \text { I }}$ & $\mathrm{P}_{2 \text { II }}$ & $\mathrm{P}_{2 \text { III }}$ & \\
\hline $\mathrm{P}_{3}$ & $\mathrm{P}_{3 \text { I }}$ & $\mathrm{P}_{3 \text { II }}$ & $\mathrm{P}_{3 \text { III }}$ & \\
\hline
\end{tabular}

Obyek dalam penelitian ini adalah bakteri Vibrio spp pada ikan kerapu macan, yang diberi ekstrak jeruk nipis dengan konsentrasi yang berbeda.

\section{HASIL DAN PEMBAHASAN}

Data hasil pengkuran zona hambat pada ektrak jeruk nipis terhadap daya penghambat pertumbuhan bakteri Vibrio sp dapat dilihat pada Tabel 2 berikut:

Tabel 2. Hasil pengujian zona hambat ekstrak jeruk nipis terhadap penghambatan pertumbuhan bakteri

Vibrio sp pada ikan kerapu macan (E. fuscogatattus).

\begin{tabular}{|c|c|c|c|c|c|}
\hline \multirow{2}{*}{ Perlakuan } & \multicolumn{3}{|c|}{ Ulangan } & \multirow{2}{*}{ Jumlah $(\mathrm{cm})$} & \multirow{2}{*}{ Rata-rata } \\
\cline { 2 - 5 } & I & II & III & & 0,07 \\
\hline Kontrol & 0 & 0 & 0,2 & 0,2 & 0,14 \\
\hline $10 \%$ & 0,15 & 0,15 & 0,12 & 0,42 & 0,11 \\
\hline $20 \%$ & 0,12 & 0 & 0,3 & 0,32 & 0,17 \\
\hline $30 \%$ & 0,5 & 0 & 0 & 0,5 & 0,12 \\
\hline & 0,32 & 0,15 & 0,35 & 1,44 & \\
\hline
\end{tabular}

Sumber Data: Data Primer 2013

Berdasarkan tabel hasil analisis rancangan Acak Lengkap diatas, terlihat bahwa ekstrak jeruk nipis dapat menghambat pertumbuhan bakteri Vibrio sp. Jumlah diameter zona hambat pada tiap kosentrasi berbeda-beda. Diameter zona hambat berturut-turut untuk kosentrasi adalah $10 \%(0,14 \mathrm{~cm}), 20 \%(0,11)$, dan $30 \%(0,17)$. Hal ini mengindikasikan bahwa ekstrak jeruk nipis jika kosentrasi yang di gunakan semakin besar maka zona hambat yang terbentuk semakin luas.

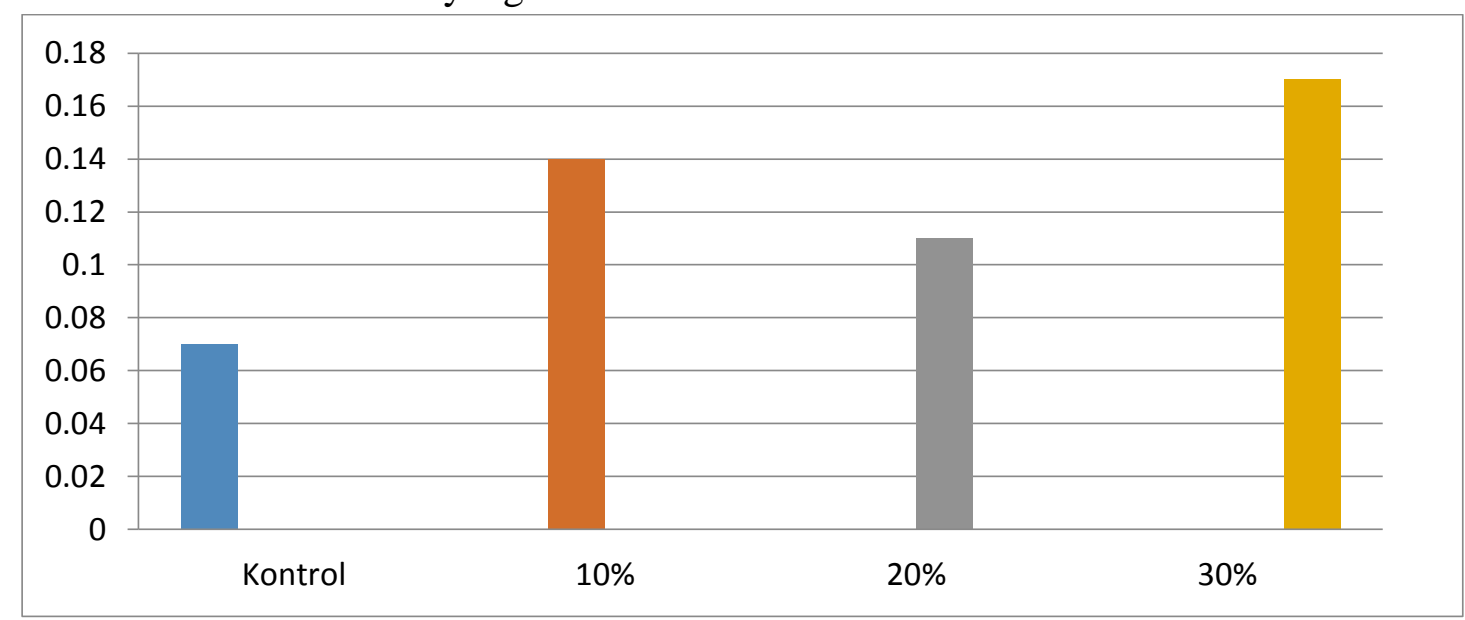

Gambar 1. Hubungan antara Konsetrasi Ekstrak Jeruk Nipis dengan Daya Hambat 
Berdasarkan grafik tersebut, terlihat bahwa pada kosentrasi (C) yaitu dengan menggunakan air (aquades) juga terlihat dapat menghambat pertumbuhan Vibrio $s p$ dengan rata-rata zona hambat sebesar $0,07 \mathrm{~cm}$. Dari grafik tersebut juga menunjukan bahwa kosentrasi optimum ekstrak jeruk nipis berada pada kosentrasi $20 \%$ dengan menghasilkan daya hambat $0,11 \mathrm{~cm}$, pada kosentrasi $10 \%$ zona hambat yang terbentuk dengan rata-rata $0,14 \mathrm{~cm}$, serta kosentrasi $30 \%$ zona hambat rata-rata yang terbentuk yaitu $0,17 \mathrm{~cm}$. Berdasarkan hal tersebut dapat disimpulkan semakin tinggi aktivitas daya hambat ektrak jeruk nipis maka semakin luas zona bening yang terbentuk.

Selanjutnya untuk mengetahui perbedaan-perbedaan tersebut dari setiap perlakuan maka dilakukan pengujian hipotesis terhadap data hasil pengamatan dengan menggunakan analisis varians untuk mengetahui pengaruh dari ke tiga level kosentrasi terhadap daya hambat pertumbuhan bakteri Vibrio sp. Data hasil analisis Varians dapat dilihat pada Tabel 3 berikut:

Tabel 3 Hasil analisis Varians (ANAVA).

\begin{tabular}{|c|c|c|c|c|c|c|}
\hline \multirow{2}{*}{$\begin{array}{c}\text { Sumber } \\
\text { Keragaman (SK) }\end{array}$} & $\begin{array}{c}\text { Derajat } \\
\text { Bebas (db) }\end{array}$ & $\begin{array}{c}\text { Jumlah } \\
\text { Kuadrat (JK) }\end{array}$ & $\begin{array}{c}\text { Kuadrat Tengah } \\
(\mathrm{KT})\end{array}$ & F Fitung & $5 \%$ & $1 \%$ \\
\cline { 4 - 7 } & 3 & 0,0168 & 0,0056 & 0,1696 & 4,07 & 7,59 \\
\hline Perlakuan & 8 & 0,2642 & 0,0330 & & & \\
\hline Galat & 11 & 0,281 & & & & \\
\hline Total & & & & & & \\
\hline
\end{tabular}

Keterangan : Tidak Nyata Karena $\mathrm{F}_{\text {hitung }}<\mathrm{F}_{\text {tabel }} 5 \% \mathrm{KK}=150,8 \%$

Berdasarkan tabel tersebut terlihat bahwa $\mathrm{F}_{\text {hitung }}<\mathrm{F}_{\text {tabel }}$ 5\% dengan demikian berarti bahwa $\mathrm{H}_{\mathrm{o}}$ di terimah dan $\mathrm{H}_{\mathrm{I}}$ di terimah. Secara statistik hasil uji menunjukan bahwa tidak ada pengaruh nyata ekstrak jeruk nipis terhadap daya hambat pertumbuhan bakteri Vibrio sp, tetapi secara deskriptif dapat dilihat ada pengaruh yang sangat nyata pada ekstrak jeruk nipis terhadap daya hambat pertumbuhan bakteri Vibrio Sp. Dimana, dapat dilihat pada daerah jernin (warna bening) disekeliling kertas uji (paper disk), yang mengindikasikan adanya zona hambatan pada media yang berarti bahwa ekstrak jeruk nipis memiliki efektifitas dalam menghambat pertumbuhan bakteri Vibrio sp. Dan sebagai buktinya nyata terdapat hasil rata-rata yang berbeda dari setiap perlakuan.

Salah satu zat yang terkandung dalam buah jeruk nipis (Citrus aurantifolia) adalah limonen. Limonen adalah salah satu senyawa karbon yang menjadi 95\% bagian dari minyak dalam kulit jeruk nipis, dan buah jeruk nipis digunakan untuk memberikan aroma jeruk pada pembersih rumah tangga. Selain memberikan bau, di dalam zat ini mengandung anti bakteri dan jamur. Kandungan limonene pada jeruk memiliki kemampuan dalam menurunkan $\mathrm{pH}$ medium, sehingga bakteri tidak dapat bertahan pada kondisi tersebut. Selain itu, senyawa asam mampu melisis dinding sel bakteri dan mengakibatkan sitoplasma sel akan keluar dan sel akan mengalami kematian 


\section{KESIMPULAN}

1. Terdapat pengaruh ekstrak jeruk nipis (Citrus aurantifolia) terhadap pertumbuhan bakteri Vibrio sp. pada ikan kerapu macan (Epinephelus fuscogatattus). Hal ini dibuktikan dengan hasil $F_{\text {hitung }}>F_{\text {tabel }}(20,535>4,07)$.

2. Besar pengaruh ekstrak jeruk nipis (Citrus aurantifolia) terhadap pertumbuhan bakteri Vibrio sp. pada ikan kerapu macan (Epinephelus fuscogatattus) adalah 0,06\%

\section{SARAN}

1. Diharapkan ada penelitian lanjutan dengan menggunakan konsentrasi ekstrak jeruk nipis yang lebih dari $30 \%$.

2. Dapat dilakukan penelitian lanjutan terhadap penghambatan jenis bakteri lain.

3. Hasil penelitian ini dapat menjadi referensi bagi mahasiswa biologi khususnya untuk melakukan penelitian obat - obatan.

4. Sebagai bahan masukan buat instansi lain maupun peneliti lain untuk dapat mengembangkan penelitian dikemudian hari.

\section{DAFTAR PUSTAKA}

Agus Irianto, 2005. Patologi Ikan Teleostei Cet I. Yogyakarta: Gajah madah university

Ali hanafiah, 2010. Rancangan Percobaan Teori dan Aplikasi. Jakarta: PT Raya Grafindo Persada

Benenson AS, Islam MR, Greenough WB. 1964. Rapid Identification Of Vibrio Cholera. Dharma, Ar. 1985. Tanaman Obat Tradisional Indonesia, Jakarta : Balai Pustaka

Doni Setianto. 2007. Usaha Budidaya Ikan Kerapu Cet I. Yogyakarta: Pustaka Baru Press

Rahayu. Tanpa Tahun. Keragaman dan Keberadaan Penyakit Bacterial dan ParasitikBenih Kerapu Macan Epinephelus fuscoguttatus di Karamba Jaring Apung,

W.J.S. Poerwadarminta. 1976. Kamus Umum Bahasa Indonesia Cet. V. Jakarta: Balai Pustaka. 